\title{
STIMULASI PSIKOSOSIAL DAN PENGARUHNYA PADA KARAKTER ANAK YANG BERSEKOLAH DAN TIDAK BERSEKOLAH DI TAMAN BERMAIN SEMAI BENIH BANGSA, KABUPATEN ACEH UTARA, PROVINSI NAD
}

Psycho Social Stimulation and Its Influence to Character of Children Attending TBA-SBB and Not TBA-SBB in Aceh Utara District, NAD Province

$$
\text { Dwi Hastuti }{ }^{1}, \text { Alfiasari }^{1}
$$

\begin{abstract}
The research was a part of umbrella research which was conducted to evaluate a preschool model established by Indonesia Heritage Foundation and Exxon Mobil Oil at District Aceh Utara, NAD Province, known as Taman Bermain Anak-Semai Benih Bangsa (TBA-SBB). Study design was a cross sectional survey which was done on April to June 2007. The subdistricts selected in the study was purposively chosen in order to compare performance of those attending TBA-SBB, kindergarten (TK) and non preschooler (no preschool education) as control group of the study. From 7 locations there was 7 TBA-SBB, 7 kindergartens and 7 control group which include 10 children per location, for a total of 210 children and their families as sample of the study. Results showed that psycho-social stimulation of those children attending school (TBA-SBB and TK) was significantly higher than control group, while there was no significance difference found between TBASBB dan TK. Character of children attending TBA-SBB was significantly the highest compare to the two groups, while children from TK was higher than control group. This finding showed that in term of child's character children from TBA-SBB was better although family social economic status is relatively lower than those children from TK. Statistical analysis found that psycho-social stimulation at home had no significant influence while school background (TBA-SBB>TK) was significantly influenced to child's character and the influence of TBA-SBB is higher than TK. Beside child's gender (girls>boys) and increasing age of children also significantly influence to child's character.
\end{abstract}

Keywords: psycho-social stimulation, character, preschools, school background

\section{PENDAHULUAN}

Era globalisasi serta permasalahan multidimensional yang dihadapi bangsa ini membutuhkan sumberdaya manusia yang berkualitas. Pendidikan sejak usia dini dipandang sebagai salah satu upaya strategis bagi terbentuknya kualitasanak yang lebih baik, secara akademik dan non-akademik (Cotton \& Conklin 2005; Megawangi 2004).

Pendidikan bagi anak usia dini telah cukup lama dilaksanakan di Indonesia, akan tetapi angka cakupan partisipasi anak usia prasekolah pada Program PAUD masih relatif kecil (20\%) dibandingkan negara berpendapatan rendah lainnya yang mencapai 24\% (Hastuti 2006). Di Propinsi Nangroe Aceh Darussalam, angka cakupan partisipasi anak usia prasekolah pada Proram PAUD hanya 5 persen. Kondisi ini dikarenakan campur tangan pemerintah dalam program PAUD masih kecil dengan besar anggaran pendidikan yang teralokasikan untuk PAUD mencapai kurang dari 2 persen, sementara pihak swasta dan masyarakatlah yang paling besar peranannya dalam mendidik anak usia prasekolah. Di Provinsi NAD, khususnya di Kabupaten Aceh Utara Taman Bermain Anak Semai Benih Bangsa (SBB) adalah kelompok prasekolah yang didirikan atas kerjasama Indonesia Heritage Foundation dan Exxon Mobil Oil sejak tahun 2003, dan didukung oleh Pemerintah Daerah. Sebuah penelitian payung dilakukan tahun 2007 sebagai 
kerjasama Departemen IImu Keluarga dan Konsumen dengan Exxon Mobil Oil untuk mengevaluasi TBA-SBB. Penelitian ini merupakan sebagian dari penelitian payung tersebut dan bertujuan untuk mengetahui (i) perbedaan stimulasi psikososial yang dilakukan orang tua (ibu/pengasuh) pada anak yang bersekolah di TBASBB dan yang tidak bersekolah di TBA-SBB (TK atau tak bersekolah); (ii) perbedaan kualitas karakter pada anak yang bersekolah di TBA-SBB dan tidak SBB; (iii) pengaruh stimulasi psikososial dan latar belakang prasekolah terhadap karakter anak.

\section{METODE PENELITIAN}

Disain, Lokasi, dan Waktu Penelitian

Penelitian ini merupakan cross sectional study dengan memfokuskan analisis pada perbedaan kualitas karakter anak yang bersekolah dan tak bersekolah di TBA-SBB dan faktorfaktor yang mempengaruhinya. Penelitian dilakukan di Kabupaten Aceh Utara, Propinsi Nanggroe Aceh Darussalam dari bulan April sampai dengan Juni 2007.

\section{Populasi dan Contoh Penelitian}

Populasi penelitian ini adalah seluruh anak yang berusia 5-7 tahun (usia pra sekolah), yang terdiri dari kelompok anak yang bersekolah di TBA-SBB (Taman Bermain Anak Semai Benih Bangsa) dan TK Formal serta kelompok anak yang tidak bersekolah di 22 kecamatan yang tersebar di Kabupaten Aceh Utara, NAD. Dalam penentuan dan seleksi contoh, tahap awal yang dilaksanakan adalah menentukan lokasi kecamatan. Pemilihan kecamatan dilakukan secara purposive. Dengan memperhatikan kondisi sosial ekonomi masyarakatnya, terpilih 3 (tiga) kecamatan, yaitu : (1) Kecamatan Nisam mewakili wilayah dengan kondisi sosial ekonomi masyarakat rendah, (2) Kecamatan Syamtalira Aron mewakili wilayah dengan kondisi sosial ekonomi masyarakat sedang, dan (3) Kecamatan Baktiya mewakili wilayah dengan kondisi sosial ekonomi masyarakat yang relatif lebih baik. Namun, dengan mempertimbangkan keberadaan dan jumlah TK/SBB, lokasi penelitian diperluas ke Kecamatan Samudera dan Kecamatan Baktiya Barat.

Pada setiap TBA-SBB dipilih secara purposive 10 (sepuluh) anak berusia 5-7 tahun yang sedang belajar di Kelas $B$, dengan kriteria bertempat tinggal dekat dengan TBA-SBB, sehingga jumlah contoh keseluruhan untuk TBA-SBB adalah 70 (tujuh puluh) orang. Sementara itu, untuk kelompok pembanding yang berasal dari TK formal dipilih dengan mekanisme berikut ini. Setelah ditentukan 7 (tujuh) TBA-SBB yang dijadikan contoh penelitian, maka dipilih secara purposive TK formal yang lokasinya berasal dari satu kecamatan contoh (kecuali 1 TBA-SBB contoh di Kecamatan Syamtalira Aron yang pasangan TK formal contoh berasal dari Kecamatan Samudera) dan pengajarnya tidak pernah mengikuti Pelatihan Karakter, sehingga terdapat 7 (tujuh) TK formal yang juga menjadi contoh penelitian. Dari TK formal tersebut juga dipilih secara purposive 10 (sepuluh) anak siswa berusia 5-7 tahun yang sedang belajar di Kelas B, dengan kriteria mempunyai tempat tinggal dekat dengan TK formal terpilih.

Begitu pula dengan kelompok anak usia pra sekolah (5-7 tahun) yang tidak bersekolah di TBA-SBB atau TK formal, yang selanjutnya disebut sebagai kelompok kontrol. Setelah ditentukan 7 (tujuh) TBA-SBB yang dijadikan contoh penelitian, maka dipilih secara purposive 10 (sepuluh) anak usia pra sekolah (5-7 tahun) yang tidak bersekolah. Oleh karenanya, dari total dari 7 (tujuh) lokasi TBA-SBB contoh terdapat 210 anak usia pra sekolah beserta keluarganya yang menjadi contoh penelitian ini. Dari 210 contoh terpilih terdapat dua contoh yang drop out 
karena sakit dan tidak bersedia melengkapi pengumpulan datanya, sehingga terdapat 208 contoh dalam penelitian ini.

\section{Pengumpulan Data}

Data primer yang disajikan dalam artikel ini dikumpulkan melalui wawancara langsung kepada keluarga dan pengukuran kepada anak, dengan alat bantu kuesioner dan checklist.

\section{Pengolahan dan Analisis Data}

Analisis perbedaan stimulasi psikososial antara peserta TBA-SBB, TK, dan kelompok kontrol dilakukan dengan menggunakan uji beda Anova. Pengolahan data guna menganalisis perbedaan karakter anak peserta TBASBB, TK, dan kelompok kontrol digunakan uji beda Anova yang dilanjutkan dengan Uji Tukey untuk melihat perbedaan antar kelompok. Untuk lebih melihat perbedaan karakter anak dilakukan pula analisis "covariat" dengan menjadikan peubah pendapatan, pendidikan ayah, pengasuhan, lama sekolah sebagai co-variat peubah sedangkan fixed factor adalah kelompok anak (SBB, TK dan kontrol), serta analisis regresi linear untuk melihat pengaruhnya.

\section{HASIL DAN PEMBAHASAN}

Stimulasi Psikososial

Salah satu aspek penting dalam pengasuhan anak adalah penyediaan lingkungan yang kondusif bagi perkembangan anak (Seifert \& Hoffnung 1987, Papalia \& Olds 1989, Turner \& Helms 1991). Menurut Caldwell \& Bradley (1984), lingkungan di mana anak berada sangat berpengaruh terhadap perkembangan anak.

Untuk keluarga dengan anak usia 3 - 6 tahun, Caldwell \& Bradley (1984) menggunakan 55 parameter untuk menilai lingkungan yang disediakan oleh keluarga bagi perkembangan anak. Parameterparameter tersebut terbagi dalam delapan subskala, yaitu : (1) Stimulasi belajar; (2) Stimulasi bahasa; (3) Lingkungan fisik; (4) Kehangatan dan penerimaan/kebanggaan, kasih sayang; (5) Stimulasi akademik; (6) Modelling;

Pengalaman/pengetahuan dan keterampilan (variasi stimulasi); dan (8) Hukuman fisik. Sementara itu, untuk keluarga dengan anak usia lebih dari 6 tahun, Caldwell \& Bradley (1984) menggunakan 59 parameter yang terbagi dalam delapan subskala, yaitu : (1) Respon emosional dan verbal; (2) Dukungan terhadap pematangan anak; (3) Iklim emosional; (4) Pengalaman dan alat untuk merangsang pertumbuhan; Penyediaan stimulasi aktif;

Partisipasi keluarga dalam stimulasi pengalaman; (7) Keterlibatan ayah; dan (8) Aspek lingkungan fisik.

Hasil penelitian ini menunjukkan bahwa stimulasi psiko social pada kategori kurang paling banyak ditemukan pada kelompok kontrol, dan paling sedikit pada kelompok TK. Sebaliknya, keluarga yang memiliki lingkungan perkembangan kategori baik paling banyak ditemui pada kelompok TK, dan paling sedikit pada kelompok kontrol. Bila dilihat dari skor rata-rata HOME, dapat dilihat bahwa keluarga kelompok TK memiliki skor rata-rata paling tinggi, sementara kelompok kontrol memiliki skor ratarata paling rendah dan menunjukkan secara signifikan lebih rendah dibanding dua kelompok lainnya $(p<0.05)$. Sementara itu, skor HOME kelompok TBA-SBB dan TK tidak berbeda nyata. Hal ini berarti bahwa stimulasi psikososial yang diterima anak di rumah pada kelompok TBASBB dan TK relatif sama, dan secara signifikan lebih baik dari kelompok control (Gambar 1). 


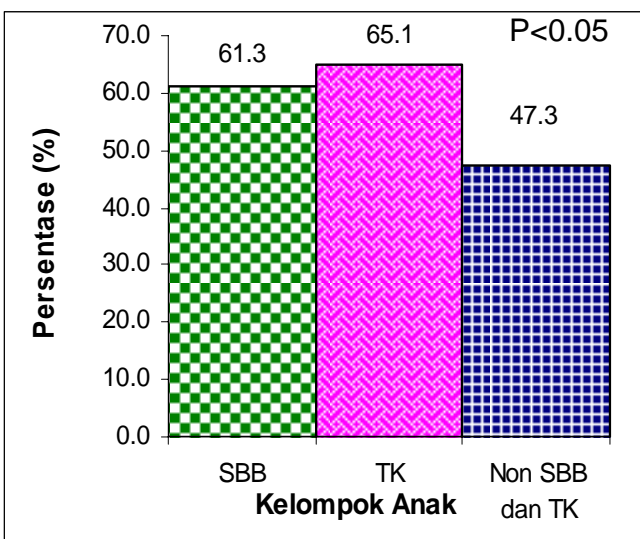

Gambar 1. Rata-rata skor HOME terstandarisasi (\%) pada kelompok anak
Bila lingkungan perkembangan anak dianalisis lebih rinci, maka hasil penelitian ini menunjukkan bahwa dalam aspek stimulasi belajar, stimulasi bahasa, kehangatan dan penerimaan, stimulasi akademik, variasi stimulasi, dan hukuman pada anak berusia $<6$ tahun, skor kelompok TK cenderung lebih tinggi dari dua kelompok lainnya. Sementara itu, dalam aspek lingkungan fisik dan modelling, skor kelompok TBA-SBB lebih tinggi dari dua kelompok lainnya. Hasil analisis statistik membuktikan bahwa lingkungan perkembangan antara kelompok TBA-SBB, TK dan kontrol berbeda secara signifikan (Tabel 1).

Tabel 1. Capaian rata-rata skor stimulasi psikososial menurut kelompok

\begin{tabular}{|l|c|c|c|c|}
\hline \multicolumn{1}{|c|}{ Skor HOME } & SBB & TK & Non SBB/TK & \multirow{2}{*}{ p-value } \\
\cline { 2 - 4 } & Mean \pm sd & Mean \pm sd & Mean \pm sd & \\
\hline 1. Stimulasi belajar (11 item) & $4.3 \pm 2.6$ & $5.3 \pm 3.1$ & $1.6 \pm 1.6$ & 0.00 \\
\hline 2. Stimulasi bahasa (7 item) & $6.1 \pm 1.3$ & $6.4 \pm 0.9$ & $5.1 \pm 1.7$ & 0.00 \\
\hline 3. Lingkungan fisik (7 item) & $4.9 \pm 1.6$ & $4.7 \pm 1.7$ & $3.3 \pm 2.0$ & 0.00 \\
\hline 4. Kehangatan \& penerimaan (7 item) & $4.8 \pm 1.9$ & $5.1 \pm 1.7$ & $3.5 \pm 2.2$ & 0.00 \\
\hline 5. Stimulasi akademik (5 item) & $4.3 \pm 1.1$ & $4.4 \pm 1.4$ & $3.4 \pm 1.5$ & 0.00 \\
\hline 6. Modelling (5 item) & $3.8 \pm 1.1$ & $3.8 \pm 1.2$ & $3.1 \pm 1.2$ & 0.00 \\
\hline 7. Variasi stimulasi (9 item) & $4.0 \pm 1.9$ & $4.9 \pm 1.8$ & $2.5 \pm 1.8$ & 0.00 \\
\hline 8. Hukuman (4 item) & $3.0 \pm 1.5$ & $3.3 \pm 1.3$ & $3.1 \pm 1.4$ & 0.60 \\
\hline & & & & \\
\hline
\end{tabular}

Hasil penelitian pada ketiga kelompok contoh dengan anak usia di atas 6 tahun menunjukkan bahwa dalam aspek respon emosional dan verbal serta iklim emosional, skor kelompok TBA-SBB cenderung lebih tinggi dari dua kelompok lainnya. Dalam aspek dukungan terhadap anak, kelompok kontrol cenderung lebih tinggi dari dua kelompok lainnya. Dalam aspek pengalaman dan stimulasi pertumbuhan, stimulasi aktif, partisipasi keluarga, keterlibatan ayah, lingkungan fisik, kelompok TK cenderung lebih tinggi dari dua kelompok lainnya. Namun demikian, hasil analisis statistik pada ketiga kelompok contoh dengan anak usia lebih dari 6 tahun menunjukkan bahwa dalam semua aspek lingkungan perkembangan anak, tidak ada perbedaan antar ketiga kelompok penelitian (lihat Tabel 2). Hal ini memperlihatkan bahwa dalam menstimulasi anak di atas usia 6 tahun, keluarga pada kelompok TBASBB, TK, maupun kontrol memberikan lingkungan perkembangan anak yang sama bagi anaknya. Diduga hal ini disebabkan oleh persepsi orang tua yang sama pada ketiga kelompok contoh, yaitu bahwa ketika anak sudah berusia 6 tahun ke atas, keluarga menyerahkan pendidikan atau stimulasi psikososial anak sepenuhnya kepada sekolah (guru). 
Tabel 2. Capaian rata-rata skor home pada kelompok anak usia $>6$ tahun

\begin{tabular}{|l|c|c|c|c|}
\hline \multicolumn{1}{|c|}{ Skor HOME } & SBB & TK & $\begin{array}{c}\text { Non } \\
\text { TK/SBB }\end{array}$ & $\begin{array}{c}\text { p- } \\
\text { value }\end{array}$ \\
\cline { 2 - 4 } & Mean \pm sd & Mean \pm sd & Mean \pm sd & \\
\hline 1. Respon emosi\&verbal (10 item) & $7.0 \pm 3.0$ & $6.5 \pm 1.6$ & $6.3 \pm 2.5$ & 0.72 \\
\hline 2. Dukungan thdp anak (7 item) & $4.6 \pm 1.8$ & $5.2 \pm 1.9$ & $5.3 \pm 1.7$ & 0.48 \\
\hline 3. Iklim emosional (8 item) & $4.8 \pm 1.0$ & $4.5 \pm 1.1$ & $4.6 \pm 1.3$ & 0.70 \\
\hline $\begin{array}{l}\text { 4. Pengalaman \& stimulasi pertumbuhan (8 } \\
\text { item) }\end{array}$ & $2.9 \pm 1.9$ & $3.4 \pm 2.1$ & $2.3 \pm 2.1$ & 0.43 \\
\hline 5. Stimulasi aktif (8 item) & $2.9 \pm 1.6$ & $3.2 \pm 1.3$ & $2.3 \pm 2.1$ & 0.36 \\
\hline 6. Partisipasi keluarga (6 item) & $2.2 \pm 1.4$ & $3.1 \pm 1.4$ & $2.4 \pm 1.6$ & 0.17 \\
\hline 7. Keterlibatan ayah (4 item) & $6.9 \pm 3.4$ & $8.5 \pm 3.5$ & $7.7 \pm 3.7$ & 0.32 \\
\hline 8. Lingkungan fisik (8 item) & $4.4 \pm 2.1$ & $4.8 \pm 2.6$ & $4.4 \pm 2.5$ & 0.84 \\
\hline
\end{tabular}

Karakter Anak

Manusia yang berkarakter adalah individu yang mengetahui tentang kebaikan, menginginkan dan mencintai kebaikan serta melakukan kebaikan (Lickona 1992, Lickona 1994). Karakter anak yang diukur dalam penelitian ini mencakup 9 pilar karakter yang mencakup : 1) Cinta Tuhan dan ciptaan-Nya; 2) Kemandirian dan tanggungjawab; 3) Jujur, amanah dan dapat dipercaya; 4) Hormat dan santun; 5) Dermawan, tolong menolong dan kerjasama; 6) Percaya diri, kreatif dan pekerja keras; 7) Kepemimpinan dan keadilan; 8) Rendah hati; dan 9) Toleransi, cinta damai dan persatuan.

Karakter cinta Tuhan dan ciptaan-Nya menunjukkan ketaatan terhadap Tuhan dan kecintaan terhadap makhluk hidup ciptaan Tuhan. Dari hasil penelitian terlihat bahwa karakter cinta Tuhan dari anak TBA-SBB dan TK berbeda signifikan dengan anak kelompok kontrol. Perbedaan cukup besar terdapat pada

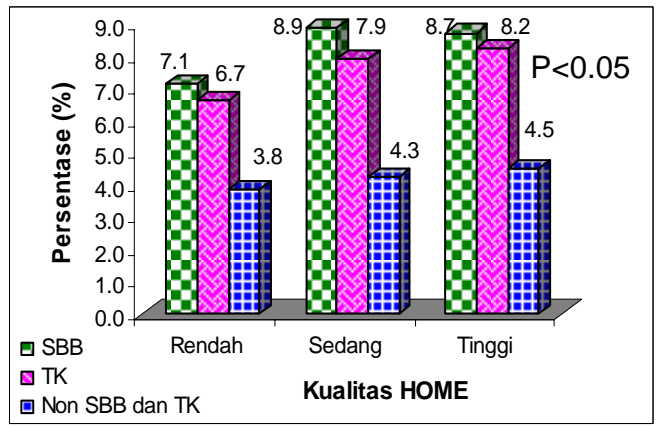

Gambar 2. Skor karakter cinta Tuhan dan ciptaan-Nya menurut tingkat stimulasi psikososial kemampuan anak yang telah bersekolah (baik TBA-SBB maupun TK) untuk mengerti doa dan menjalankan ibadah sesuai dengan tuntunan agama Islam.

Dari hasil uji lanjutan dengan menjadikan kelompok anak dan kualitas pengasuhan (yang diukur dengan instrumen HOME) sebagai "covariat" maka terlihat suatu kecenderungan bahwa dengan kualitas pengasuhan yang semakin baik, maka kualitas karakter cinta Tuhan dan ciptaan-Nya semakin baik pula (Gambar 2). Hal ini mencerminkan peran kualitas pengasuhan di rumah dan kelompok anak TBA-SBB atau TK dalam pembentukan karakter cinta Tuhan dan ciptaan-Nya. Hasil penelitian ini sejalan dengan temuan penelitian di Kota dan Kabupaten Bogor (Hastuti, 2006) bahwa karakter anak ditentukan antara lain oleh perlakuan sekolahnya dan kualitas pengasuhan yang diterima anak di rumah.

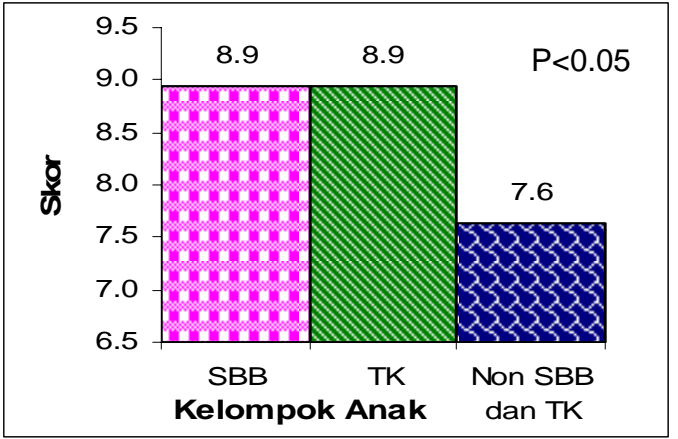

Gambar 3. Skor karakter jujur, amanah, dan dapat dipercaya menurut kelompok anak 
Karakter jujur, amanah, dan dapat dipercaya adalah karakter penting yang diperlukan sebagai identitas bangsa. Fukuyama (1992) mengungkapkan bahwa kejujuran, tanggungjawab, dan bisa dipercaya (trusted) adalah tiga karakter utama yang dapat menentukan kemajuan bangsa. Pada penelitian ini karakter jujur, amanah, dan dapat dipercaya ini dilihat dari kemampuan anak untuk berperilaku jujur saat menggunakan barang milik orang lain, saat menemukan barang yang ditemukan, atau saat menginginkan uang untuk aneka keperluannya. Anak dari kelompok TBA-SBB dan TK hampir sama dalam kejujuran dan amanahnya, namun perbedaan signifikan terdapat antara kelompok TBA-SBB dan TK dengan anak kelompok kontrol (Gambar 3). Anak kelompok kontrol umumnya lebih sering lupa dalam menyampaikan pesan, serta kurang mampu dalam melaporkan barang yang ditemukannya kepada orang dewasa di sekitar.

Sementara itu, pada karakater kemandirian dan tanggungjawab, diukur kematangan anak dalam menjalankan keterampilan untuk hidup mandiri dan bertanggungjawab dalam kegiatan seperti makan, mandi dan buang air. Kemandirian anak umumnya berhubungan dengan pembiasaan yang diterapkan oleh orangtua, dan lingkungan dimana anak berada. Hasil penelitian menunjukkan adanya perbedaan signifikan dalam kemandirian dan tanggungjawab antar kelompok, yaitu anak TBA-SBB lebih mandiri dibandingkan dua kelompok lainnya. Hal ini memperlihatkan bahwa anak TBA-SBB lebih mampu menunaikan tugas "self help skills" bagi anak umur pra sekolah. Bahkan kemampuan "self help skills" anak TBA-SBB lebih baik dan berbeda signifikan secara statistik $(p<0.05)$ dibandingkan anak dari kelompok TK (Gambar 4).

Anak dari kelompok kontrol menunjukkan kemampuan kemandirian dan tanggungjawab yang paling rendah, hal ini karena masih kuatnya peran dan campur tangan orangtua dalam membantu anak untuk melakukan pekerjaan pribadi (makan, mandi, buang air) yang seharusnya sudah dapat dilakukan anak usia pra sekolah sendiri. Dengan demikian, hasil ini menunjukkan kematangan anak TBA-SBB dalam menjalankan tugas perawatan dirinya, yang mencerminkan pula karakter tanggungjawabnya sebagai individu. Dalam kegiatan belajar mengajar di kelas, pada umumnya tugas kemandirian ini dialirkan di kelompok TBA-SBB dalam bentuk cerita maupun dalam bentuk perbuatan seperti menata meja belajar, mengembalikan alat permainan sesudah dipergunakan, ataupun buang air kecil sendiri.

Karakter hormat dan santun
adalah kemampuan anak mengucapkan salam, memohon izin, dan permohonan bantuan kepada orang dewasa yang ada disekitarnya. Dari hasil penelitian diperlihatkan bahwa anak TBA-SBB dan TK memiliki karakter ini lebih baik daripada anak kelompok kontrol (Gambar 5). Hasil ini menunjukkan bahwa anak yang bersekolah baik di TK maupun di TBA-SBB memiliki kesopanan dan kesantunan yang jauh lebih baik dibandingkan anak yang tidak bersekolah. Hal ini karena anakanak tersebut mendapatkan materi belajar tentang kesopanan dan kesantunan dari guru masing-masing, disamping latihan yang diterapkan oleh guru setiap hari dengan memberikan salam, cium tangan, dan ucapan kata " tolong" dan "maaf", atau "permisi". 
Hasil uji statistik menunjukkan adanya perbedaan signifikan antara kelompok TBA-SBB dan TK dengan kelompok kontrol pada karakter hormat dan santun ini. Bahkan setelah uji lanjutan dengan

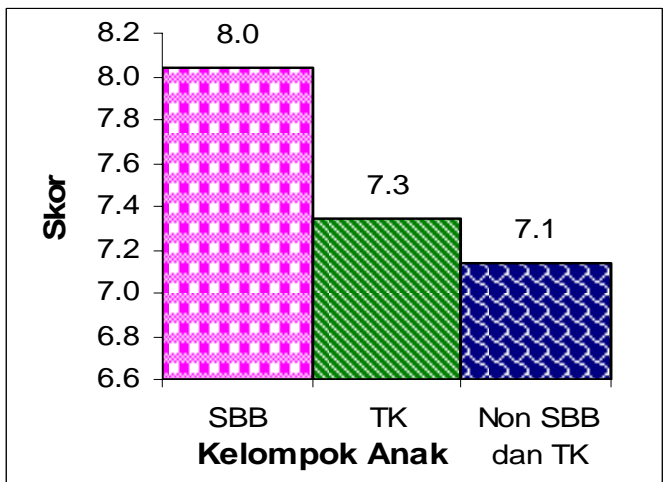

Gambar 4. Skor Karakter Kemandirian Menurut Kelompok

Karakter dermawan, suka menolong dan gotong royong adalah perilaku untuk mau membantu orangtua, tidak mengganggu dan tidak berkelahi, dan suka untuk berbagi dengan teman atau saudara di rumah. Dalam pilar karakter ini, anak dari kelompok TBA-SBB memiliki skor paling tinggi dari dua kelompok lainnya, dan anak kelompok kontrol memiliki skor paling rendah (Gambar 6). Perbedaan antar ketiga kelompok dalam perilaku dermawan dan suka menolong tersebut signifikan secara statistik, sekaligus menunjukkan pengaruh keberadaan sekolah pada karakter anak tersebut. Hal ini diduga karena guru di sekolah membiasakan anak untuk saling bekerjasama, saling tolong menolong terutama dalam menggunakan sarana di sekolah seperti alat permainan edukatif, buku cerita, alat permainan outdoor, dan sebagainya. Di samping itu, di sekolah anak ditanamkan kebiasaan untuk antri, saling menunggu dan bergiliran dalam menggunakan aneka sarana dan prasarana sekolah yang terbatas.

Pada karakter dermawan, suka menolong dan gotong royong, menjadikan kualitas pengasuhan sebagai "covariat" tetap menunjukkan bahwa semakin tinggi kualitas pengasuhan maka semakin baik karakter hormat dan santun pada anak (Gambar 6).

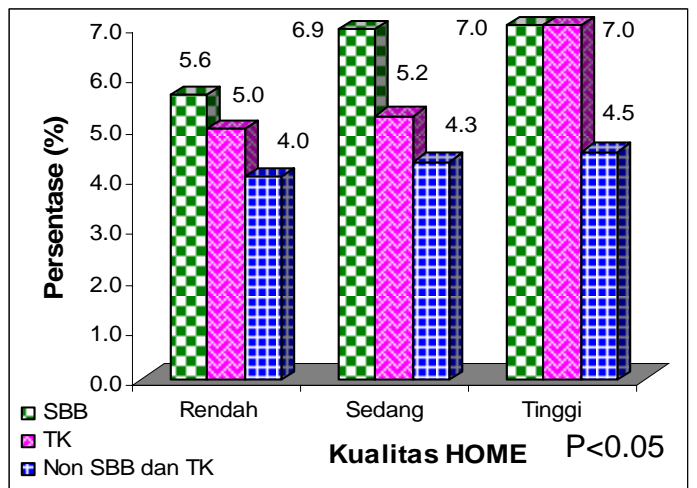

Gambar 5. Skor karakter hormat dan satun menurut kualitas pengasuhan

perbedaan signifikan hanya terdapat antara kelompok anak yang bersekolah (baik di TBA-SBB maupun di TK) dengan anak kelompok kontrol (Gambar 6), sedangkan antara anak kelompok TBA-SBB dan TK tidak terdapat perbedaan signifikan. Hal ini memperlihatkan adanya peran langsung dan tak langsung dari sekolah dalam pembentukan karakter dermawan.

Percaya diri, kreatif dan bekerja keras, adalah karakter yang menunjukkan kesungguhan seseorang untuk percaya atas kemampuan dirinya, yang dilihat dari keberanian seorang anak untuk berbicara, bernyanyi, dan tampil dalam acara tertentu yang dilangsungkan di sekolah maupun di lingkungan dimana anak tinggal. Menurut Medhus (2005) kepercayaan diri ini berguna bagi kemampuan anak untuk mengontrol diri sendiri. Dengan adanya kepercayaan terhadap dirinya sendiri tersebut maka anak akan mampu mengendalikan dirinya sehingga jika terdapat pengaruh eksternal dari teman maupun lingkungan yang dipandang kurang baik, anak akan 
mengambil keputusan dengan menggunakan akal budinya sebelum bertindak. Dari hasil penelitian terlihat bahwa karakter kepercayaan diri anak TBA-SBB jauh lebih tinggi dibandingkan anak TK sekalipun. Hasil uji statistik juga memperlihatkan

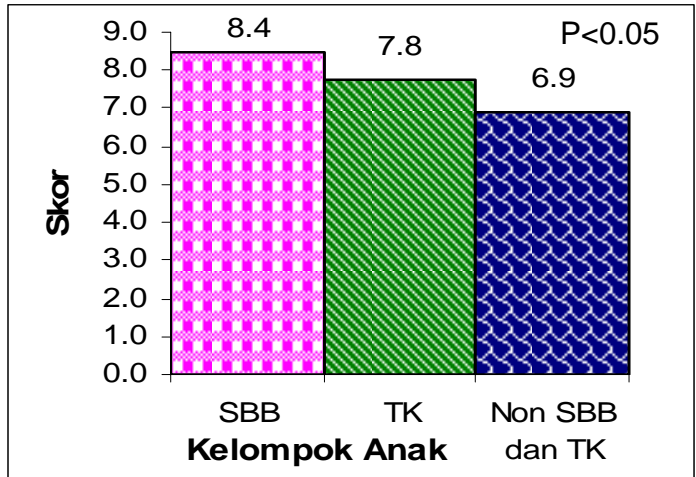

Gambar 6. Skor karakter dermawan, suka menolong dan gotong royong menurut kelompok anak

Dari uji lanjutan dengan menggunakan uji analisis "covariat" terhadap pendapatan keluarga per kapita dan kelompok anak, diperoleh hasil bahwa anak dari kelompok TBASBB tetap menunjukkan karakter kepercayaan diri yang lebih baik daripada anak kelompok TK dan kelompok kontrol. Pada Gambar 7 terlihat bahwa pada kelompok TBASBB dengan semakin tinggi pendapatan keluarganya memiliki karakter kepercayaan diri yang semakin baik. Hal ini juga menunjukkan bahwa anak kelompok TBA-SBB yang berasal dari keluarga dengan pendapatan yang sama dengan anak TK dan kontrol tetap menunjukkan perbedaan yang signifikan dalam karakter kepercayaan dirinya dibandingkan dua kelompok lainnya.

Karakter kepemimpinan ("leadership") dan keadilan ("justice") adalah perilaku yang diharapkan muncul pada sebuah budaya korporasi dan organisasi. Lebih lanjut diungkapkan bahwa kepemimpinan perbedaan yang signifikan antar kelompok. Perbedaan ini mencerminkan adanya pengaruh eksternal dan internal seperti karakateristik keluarga dan sekolah dimana keduanya berada.

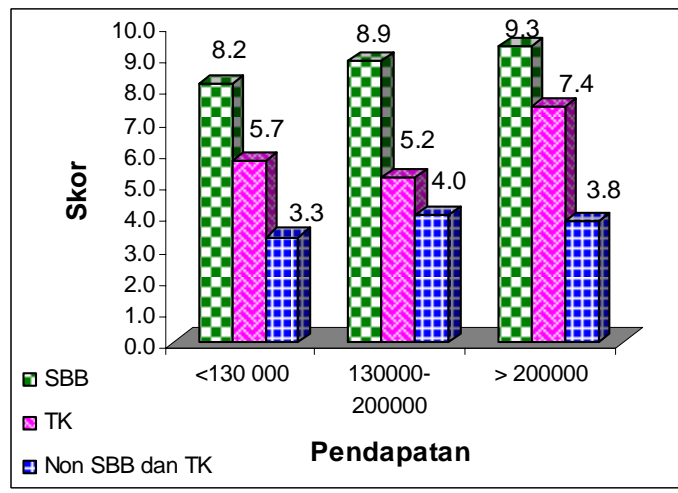

Gambar 7. Skor karakter percaya diri, kreatif, dan pekerja keras menurut tingkat pendapatan

hanya muncul dan efektif selama lingkungan budaya memberikan teladan (model), membangunnya (build), dan memeliharanya (sustain). Dari Gambar 8 terlihat bahwa anak kelompok TBA-SBB memiliki skor paling tinggi dibandingkan dua kelompok lainnya, namun secara statistik perbedaan signifikan dalam karakter kepemimpinan dan keadilan hanya ditemukan dengan kelompok kontrol.

Sementara itu, karakter rendah hati menunjukkan perilaku suka berbagi, memaafkan, dan tidak menyakiti teman. Hasil penelitian memperlihatkan bahwa secara umum, anak kelompok TBA-SBB memiliki skor karakter rendah hati paling tinggi daripada dua kelompok lainnya dan berbeda signifikan. Dari uji analisis lanjutan dengan menjadikan lama pendidikan ayah sebagai "covariat" tampak bahwa skor karakter rendah hati tidak berjalan seiring dengan peningkatan pendidikan ayahnya (Gambar 9). Pada anak kelompok TBA-SBB dan kontrol tampak bahwa 
dengan pendidikan ayah lebih dari 12 tahun maka skor karakter anak TBASBB dan kontrol lebih rendah daripada anak dengan pendidikan ayah 7-12 tahun. Namun demikian, secara

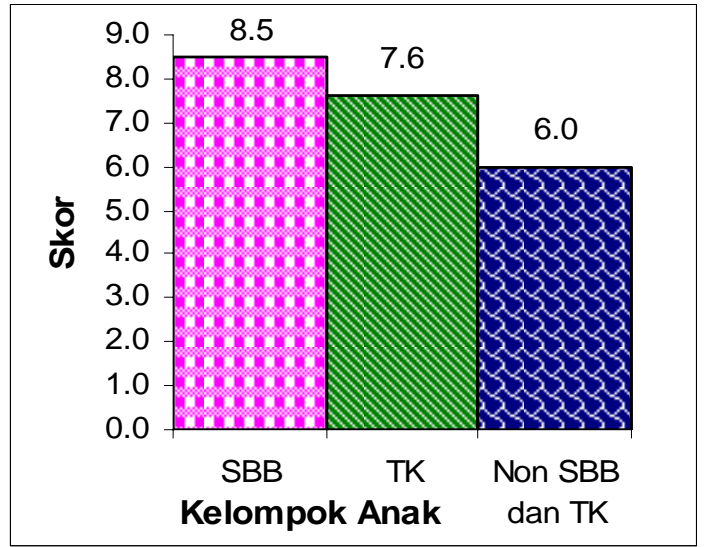

Gambar 8. Skor Karakter Kepemimpinan dan Keadilan menurut Kelompok

Anak kelompok kontrol masih memiliki skor paling rendah dalam karakter baik dan rendah hati ini, yang sekaligus menunjukkan bahwa anak yang tak memiliki latar belakang sekolah adalah anak yang paling tertinggal dalam hal karakternya. Hasil ini sekaligus memperlihatkan adanya manfaat kurikulum dan pembiasaan di sekolah pada pembentukan karakter anak.

Karakter toleransi, cinta damai, dan persatuan diukur dari kemampuan anak untuk tidak mencela teman, merusak barang orang lain, tidak suka mendorong teman saat antri dan mau meminjamkan sesuatu bila ada yang membutuhkan. Dari Gambar 10 terlihat bahwa karakter anak kelompok TBASBB paling baik daripada anak kelompok kontrol maupun anak TK. $\mathrm{Hal}$ ini menunjukkan pula bahwa keseluruhan terdapat perbedaan signifikan dalam hal karakter rendah hati antara anak kelompok TBA-SBB dengan anak TK maupun anak kontrol.

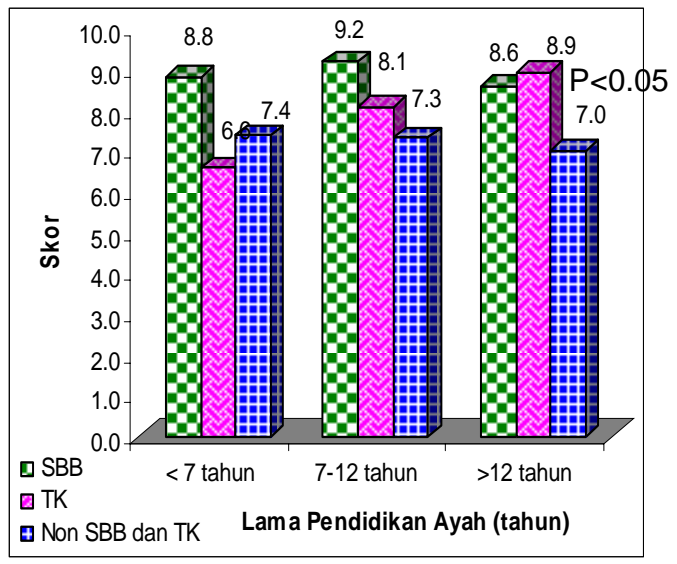

Gambar 9. Skor karakter rendah hati menurut lama pendidikan ayah

kelompok anak adalah faktor dominan yang menentukan karakter ini. Hasil uji selanjutnya dengan menjadikan kelompok anak sebagai "covariat" tetap menunjukkan bahwa anak kelompok TBA-SBB adalah paling baik dalam hal toleransi, cinta damai, dan persatuan dibandingkan dua kelompok lainnya.

Secara keseluruhan dari total skor karakter, anak kelompok TBASBB memiliki karakter paling baik daripada kelompok kontrol maupun anak kelompok TK (Gambar 11). Hasil ini sejalan dengan hasil temuan Hastuti (2006) pada anak kelompok TBA-SBB di Kota dan Kabupaten Bogor serta Kotif Depok yang juga memiliki karakter lebih baik dibandingkan anak TK dan anak kontrol. 


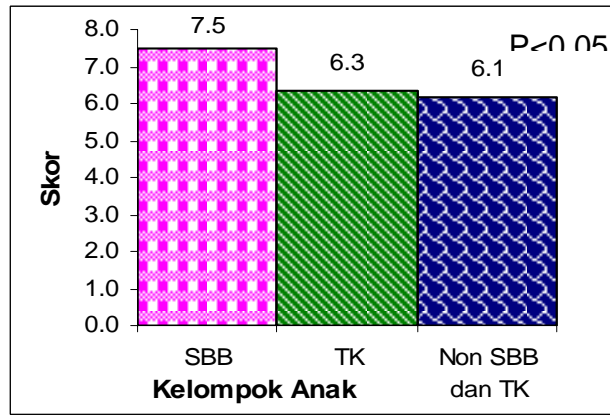

Gambar 10. Skor karakter toleransi, cinta damai menurut kelompok

Menurut Lickona (2004), salah satu strategi tepat dalam membentuk karakter anak adalah melalui kerangka kurikulum yang tepat, sosialisasi dan publikasi kurikulum karakter, pembentukan model pendidikan sekolah melalui pendekatan proses dan budaya sekolah yang menunjang pendidikan karakter. Hasil ini juga memberikan implikasi pada adanya pengaruh faktor sekolah pada pembentukan karakter anak, meskipun untuk keperluan penarikan kesimpulan diperlukan uji lanjutan untuk menentukan faktor yang berpengaruh terhadap pembentukan karakter anak.

Pada penelitian ini karakter anak dipengaruhi secara nyata oleh peubah-peubah penelitian dengan koefisien determinasi $\left(R^{2}\right)$ sebesar 0.45 . Hal ini menunjukkan bahwa $45 \%$ variasi dari karakter anak dapat dijelaskan oleh variasi dari peubahpeubah yang disajikan pada model analisis pengaruh (Tabel 3).Dari uji regresi yang dilakukan pada karakter anak maka pengaruh peubah kelompok anak adalah paling dominan dan signifikan dalam membentuk karakter anak contoh. Adanya pengaruh signifikan tersebut sekaligus menunjukkan bahwa peran institusi sekolah dalam pembentukan karakter anak dalam penelitian ini sangat dominan. Hasil ini berbeda dengan temuan Hastuti (2006) yang memperlihatkan adanya pengaruh peran keluarga melalui pengasuhan, yang cukup dominan dalam membentuk karakter anak.

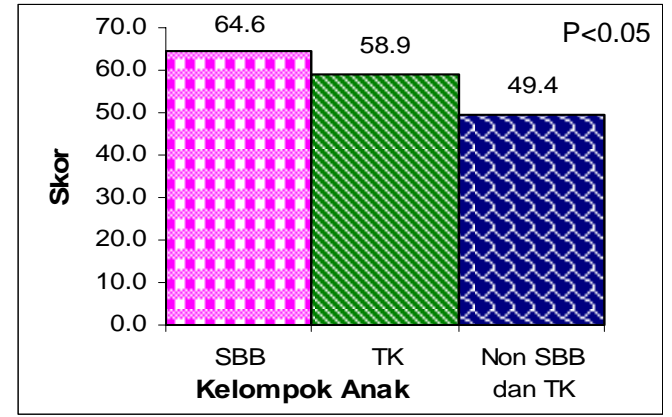

Gambar 11. Skor karakter total Menurut kelompok

Dari penelitian ini faktor yang berpengaruh terhadap skor karakter anak adalah peubah dummy sekolah 1 (bersekolah di SBB) dan 2 (TK). Koefisien regresi untuk peubah dummy sekolah 1 (bersekolah di SBB) $=13.1(p<0.01)$ dan peubah dummy sekolah 2 (bersekolah di TK)= $6.6(p<$ 0.01). Hal ini menunjukkan bahwa dikontrol dengan peubah lain di dalam model, anak-anak yang bersekolah di SBB memiliki rata-rata skor karakter 13.1 lebih tinggi dibanding dengan anak-anak yang tidak bersekolah di SBB/TK. Sementara itu, anak-anak yang bersekolah di TK memiliki ratarata skor karakter 6.6 lebih tinggi dibanding dengan anak-anak kontrol (yang tidak bersekolah di SBB/TK). Hal ini berarti bahwa dampak bersekolah di SBB terhadap karakter anak lebih besar dibanding dengan dampak bersekolah di TK.

Hasil analisis regresi juga menunjukkan bahwa peubah karakteristik anak yaitu gender anak berpengaruh sangat signifikan terhadap skor karakter anak. Anak dengan jenis kelamin laki-laki, ceteris paribus, memiliki rata-rata skor karakter yang lebih rendah dari anak perempuan $(B=4.00)$. $\mathrm{Hal}$ ini menunjukkan bahwa anak perempuan umumnya memiliki skor karakter yang lebih tinggi dibandingkan anak lakilaki. Temuan ini konsisten dengan hasil penelitian di Kabupaten dan Kota Bogor serta Kotif Depok (Hastuti, 2006). Perbedaan ini mungkin disebabkan oleh adanya perbedaan 
dalam aktifitas antar gender. Anak laki-laki cenderung lebih aktif, banyak bergerak sehingga kerap kali kurang disiplin dan/atau menyimak pembiasaan baik yang diajarkan guru.

Sementara itu, anak perempuan cenderung lebih tahan duduk dan menyimak keterangan guru, sehingga relatif mendengarkan dan mampu menyerap nilai karakter yang diajarkan. Hal ini berarti bahwa dalam proses belajar mengajar di dalam kelas, anak laki-laki perlu mendapatkan perhatian lebih terutama untuk meningkatkan partisipasinya di kelas serta rasa ingin tahu dan keterlibatan anak.

Tabel 3. Hasil Analisis Regresi tentang Faktor Berpengaruh pada karakter anak

\begin{tabular}{|c|c|c|c|c|c|}
\hline \multirow[b]{3}{*}{ Variabel } & \multicolumn{4}{|c|}{ Koefisien $^{a}$} & \multirow[b]{3}{*}{ Sig } \\
\hline & \multicolumn{2}{|c|}{$\begin{array}{l}\text { Koefisien yang tidak } \\
\text { Distandarisasi }\end{array}$} & \multirow{2}{*}{$\begin{array}{c}\begin{array}{c}\text { Koefisien yang } \\
\text { Distandarisasi }\end{array} \\
\text { Beta }\end{array}$} & \multirow[b]{2}{*}{$\mathrm{t}$} & \\
\hline & $\mathrm{B}$ & Std. Error & & & \\
\hline (Konstanta) & 17.32 & 9.72 & & 1.78 & 0.08 \\
\hline Dummy Sekolah 1 (SBB) & 13.23 & 1.84 & 0.58 & 7.14 & 0.00 \\
\hline Dummy Sekolah 2 (TK) & 6.64 & 1.95 & 0.29 & 3.41 & 0.00 \\
\hline Jenis Kelamin $(1=\mathrm{lk} ; 2=\mathrm{pr})$ & 4.00 & 1.31 & 0.18 & 3.05 & 0.00 \\
\hline Jumlah Anggota Keluarga & $-2.95 \mathrm{E}-02$ & 0.38 & -0.01 & -0.08 & 0.94 \\
\hline Umur Anak & 0.21 & 0.11 & 0.12 & 1.87 & 0.06 \\
\hline Lama Pendidikan ibu & 0.40 & 0.25 & 0.13 & 1.61 & 0.11 \\
\hline Pendapatan/kapita/bulan & 5.91E-08 & 0.00 & 0.01 & 0.09 & 0.93 \\
\hline HOME & $6.85 \mathrm{E}-02$ & 0.05 & 0.12 & 1.46 & 0.14 \\
\hline Tingkat Stress Ibu & 1.44E-02 & 0.05 & 0.02 & 0.31 & 0.76 \\
\hline Keharmonisan Keluarga & 8.89E-02 & 0.05 & 0.10 & 1.68 & 0.10 \\
\hline Emotional Bonding & 2.38E-03 & 0.05 & 0.00 & 0.05 & 0.96 \\
\hline Total Skor Fisik & -0.27 & 0.23 & -0.08 & -1.14 & 0.26 \\
\hline
\end{tabular}

a. Variabel Dependen : Total Karakter

\section{SIMPULAN DAN SARAN}

Simpulan

Hasil penelitian ini menunjukkan bahwa stimulasi psikosial pada anak yang bersekolah di TK adalah paling baik, dan stimulasi psikososial anak yang berlatar pendidikan pra sekolah (SBB maupun TK) berbeda dan secara signifikan tinggi dibandingkan dengan yang tidak bersekolah (kelompok kontrol). Sementara itu, kualitas karakter anak peserta TBA-SBB lebih baik dibandingkan anak kelompok kontrol, bahkan lebih baik dibandingkan dengan anak kelompok yang bersekolah di TK. Hasil analisis statistika memperlihatkan bahwa karakter anak dalam penelitian ini ditentukan oleh peubah kesertaan dalam sekolah ( $\mathrm{SBB}>\mathrm{TK}>\mathrm{k}$ kontrol), diikuti peubah gender (perempuan>laki) dan meningkatnya umur anak, sedangkan peubah stimulasi psikososial dan karakteristik keluarga lainnya tak berpengaruh.

\section{Saran}

Hasil positif dalam kualitas karakter pada anak-anak yang bersekolah, khususnya TBA-SBB, menunjukkan bahwa pemahaman dan penerapan karakter sejak dini sangat penting dilakukan sebagai upaya untuk menghasilkan kualitas karakter 
anak yang lebih baik. Oleh karenanya, hasil penelitian ini menyarankan kepada pihak-pihak terkait (pemda, dinas pendidikan, NGO dan industri serta masyarakat sekitar) untuk mampu berpartisipasi dan mengembangkan kelompok prasekolah yang menerapkan pendidikan holistik berbasis karakter guna mendapatkan siswa dan lulusan yang lebih baik karakternya sebagai modal penting bagi pembangunan masyarakat.

\section{DAFTAR PUSTAKA}

Caldwel \& Bradley. $1984 . \quad$ Home Observation and Measurement of Environment (HOME). Arkansas.

Cotton K. \& Conklin N.F. 2001. School Improvement Research Series : Research on Early Childhood Education. NorthWest Regional Educational Laboratory.

Engle P. L, P.Menon., L. Haddad 1997. Care and Nutrition. Concept and Measurement. International Food Policy Research Institute. Washington.

Fukuyama F. 1992. Trust: The Social Virtues and the Creation of Prosperity. London : Hamish Hamilton.

1 Departemen Ilmu Keluarga dan Konsumen, IPB

Alamat Korespondensi:

Dwi Hastuti

Departemen IImu Keluarga dan Konsumen,

Fakultas Ekologi Manusia IPB

Jl. Lingkar Kampus IPB Darmaga 16680

Telp. (0251) 8628303, Fax. (0251) 8627432
Hastuti D. 2006. Anaisis Pengaruh Model Pendidikan Prasekolah pada Pembentukan Anak sehat, Cerdas dan berkarakter. Disertasi. Sekolah Pasca Sarjana, Institut Pertanian Bogor. Bogor: IPB.

Hetherington, E.M. \& Parke. (1986). Child Psychology. Singapore : McGraw-Hill Book Co.

Lickona T. 2004. Raising Good Raising Good Children: From Birth Through the Teenage Years. Bantam Books, New York, Toronto, London, Sydney, Auckland.

Miller, P.H. (1993). Theories of Developmental Psychology (3rd Ed.). New York : W.H. Freeman \& Co.

Papalia, D.E. \& Olds, S.W. 1989. Human Development. McGraw-Hill Book Company.

Santrock, John W. 1997. Life Span Development. Brown Benchmark Publisher, Madison.

Seifert, K.L. \& Hoffnung, R.J. (1987). Child and Adolescent Development. Boston : Houghton Mifflin Co.

Turner, J.S. \& Helms, D. 1991. Life Span Development. Holt, Rinehart and Winston, Inc. The Dryden Press.

Vasta, R., Haith, M M., \& Miller, SA. (1992). Child Psychologi : The Modern Science. New York : John Wiley \& Sons. Inc. 